\title{
OSOBY Z NIEPEŁNOSPRAWNOŚCIĄ W BIBLIOTECE - NURTY BADAWCZE W ZAGRANICZNYM I POLSKIM PIŚMIENNICTWIE Z ZAKRESU BIBLIOLOGII I INFORMATOLOGII
}

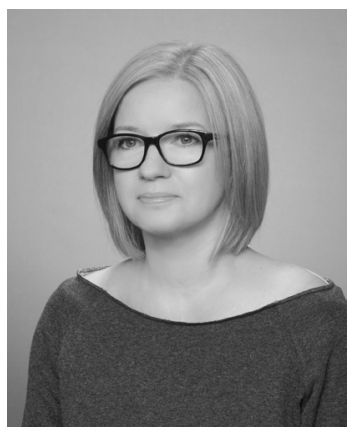

Małgorzata Fedorowicz-Kruszewska jest doktorem habilitowanym w zakresie bibliologii i informatologii, adiunktem w Instytucie Informacji Naukowej i Bibliologii Uniwersytetu Mikołaja Kopernika w Toruniu. Jej zainteresowania naukowe koncentrują się wokół mediów i usług informacyjnych adresowanych do grup zagrożonych wykluczeniem społecznym, wykorzystania koncepcji zrównoważonego rozwoju w instytucjach kultury oraz promocji instytucji kultury. Jest autorką trzech książek, kilkudziesięciu artykułów oraz redaktorem kilku prac zbiorowych.

SŁOWA KLUCZOWE: Osoby z niepełnosprawnością. Niepełnosprawność. Obsługa biblioteczna. Usługi informacyjne biblioteki.

STRESZCZENIE: Teza/cel artykułu - Celem artykułu jest zaprezentowanie nurtów tematycznych specjalności badawczej bibliologii i informatologii, jaką jest obsługa biblioteczno-informacyjna osób niepełnosprawnych i ich funkcjonowanie w środowisku bibliotecznym i informacyjnym oraz porównanie wątków badawczych zagranicznego i polskiego piśmiennictwa naukowego w przywołanym obszarze. Metody badań Zastosowano analizę i krytykę piśmiennictwa zagranicznego i polskiego z zakresu bibliologii i informatologii opublikowanego w latach 2010-2015. Eksploracji poddano 
zawartość publikacji zarejestrowanych w bazie abstraktowej „Library, Information Science \& Technology Abstracts” (LISTA), w „Polskiej Bibliografii Bibliologicznej” i w „Przewodniku Bibliograficznym" oraz opublikowanych w najwyżej punktowanych polskich czasopismach naukowych z obszaru bibliologii i informatologii. Wyniki i wnioski W piśmiennictwie zagranicznym wyodrębniono 9 zasadniczych nurtów badawczych podejmowanych w zakresie obsługi biblioteczno-informacyjnej osób niepełnosprawnych i ich funkcjonowania w środowisku bibliotecznym i informacyjnym. W polskiej literaturze naukowej z tego zakresu wydzielono jedynie 6 wątków tematycznych, w tym 2 reprezentowane przez 1 publikację. Najsilniejszy aktualnie nurt badań w bibliotekoznawstwie i informacji naukowej we wzmiankowanym zakresie stanowi (zarówno w przypadku piśmiennictwa obcojęzycznego, jak i rodzimego) dostęp osób z niepełnosprawnością do informacji, obejmujący tematykę dostępu do zasobów internetowych, baz danych, bibliotek cyfrowych, w mniejszym stopniu zasobów w postaci analogowej.

\section{WPROWADZENIE}

Nurty badawcze z zakresu bibliotekoznawstwa i informacji naukowej ${ }^{1}$ były już przedmiotem analiz w zagranicznym i w polskim piśmiennictwie naukowym (Aharony, 2012; Głowacka, 2008; Sosińska-Kalata, 2013). W niniejszym artykule autorka skoncentrowała się na stosunkowo wąskiej specjalności badawczej bibliologii i informatologii, jaką jest obsługa biblioteczno-informacyjna osób niepełnosprawnych oraz ich szeroko pojmowane funkcjonowanie w środowisku bibliotecznym i informacyjnym², która nie doczekała się tego typu opracowań w polskiej literaturze naukowej i niewielu w zagranicznej (Davies, 2007; Hill, 2013). Celem artykułu jest zatem zaprezentowanie nurtów tematycznych pola badawczego bibliotekoznawstwa i informacji naukowej w latach 2010-2015 oraz porównanie wątków badawczych zagranicznego i polskiego piśmiennictwa naukowego w przywołanym obszarze.

\section{METODOLOGIA BADAŃ}

Autorka analizowała zagraniczne i polskie piśmiennictwo naukowe, dotyczące obsługi biblioteczno-informacyjnej osób z niepełnosprawnością w bibliotekach oraz szeroko pojmowanego funkcjonowania osób niepełnosprawnych w środowisku bibliotecznym i informacyjnym. Wyznaczono zasięg chronologiczny obejmujący lata 2010-2015, gdyż celem artykułu była analiza najnowszych kierunków badań w XXI w., ale także porównanie uzyskanych wyników z tymi otrzymanymi w odniesieniu do piśmiennictwa anglosaskiego za lata 2000-2010, o bardzo zbliżonym

\footnotetext{
1 Zamiennie będzie używana nazwa bibliotekoznawstwo $i$ informacja naukowa oraz bibliologia $i$ informatologia.

${ }^{2}$ Uwzględniono tu m.in. zagadnienia dotyczące czytelnictwa osób niepełnosprawnych, ich potrzeb informacyjnych, prawa autorskiego w kontekście dostępu do informacji.
} 
zakresie (Hill, 2013). Założono, że eksplorowane będą bazy bibliograficzne i abstraktowe rejestrujące zagraniczne i polskie piśmiennictwo naukowe $z$ obszaru bibliologii i informatologii. Pierwszym krokiem była analiza zawartości bazy „Library, Information Science \& Technology Abstracts" (LISTA), która indeksuje ponad 560 głównych czasopism tematycznych, blisko 50 czasopism priorytetowych oraz niemal 125 wybranych czasopism. Rejestruje również książki, raporty i sprawozdania z badań. Wyszukiwano publikacje naukowe ${ }^{3}$. Otrzymano 169 wyników, które poddano selekcji, wykluczając te publikacje, które mimo przyporządkowanych haseł nie dotyczyły zagadnienia funkcjonowania osób niepełnosprawnych w bibliotece lub podejmowały je marginalnie, te które dotyczyły osób społecznie niepełnosprawnych oraz artykuły wstępne, abstrakty, recenzje i krótkie omówienia, raporty z konferencji oraz rekordy wyświetlone podwójnie. Ostatecznie analizie poddano 136 publikacji.

Więcej trudności nastręczyło wyszukanie do analiz polskiego piśmiennictwa naukowego z zakresu bibliologii i informatologii. „Polska Bibliografia Bibliologiczna" - jedyny bieżący spis bibliograficzny rejestrujący polskie piśmiennictwo z zakresu szeroko pojętej nauki o książce, w tym z bibliotekoznawstwa i informacji naukowej - ukazuje się z kilkuletnim opóźnieniem. Ostatnie zarejestrowane publikacje pochodzą z 2010 r. Aktualnie trwają prace nad tomem za 2011 r. Podobna sytuacja odnosi się do bazy za lata 20112014, która również nie jest jeszcze gotowa do udostępnienia (Szablewski, 2016). W tej sytuacji autorka postanowiła przeanalizować bazę „Przewodnik Bibliograficzny", rejestrującą wydawnictwa zwarte, opublikowane na terenie Polski oraz dodatkowo zawartość polskich czasopism bibliotekoznawczych i informatologicznych, znajdujących się w części B wykazu czasopism naukowych Ministerstwa Nauki i Szkolnictwa Wyższego (MNiSW, 2015; 2016) z najwyższą punktacją ${ }^{4}$. Przeanalizowano zawartość 13 czasopism ${ }^{5}$. Najpierw przeszukano bazę „Polska Bibliografia Bibliologiczna” za 2010 r. ${ }^{6}$,

${ }^{3}$ Kryterium wyszukiwania były hasła przedmiotowe "libraries/library” i "people with disabilities" połączone operatorem ,"and".

${ }^{4} \mathrm{~W}$ odniesieniu do czasopism z zakresu bibliologii i informatologii - od 7 do 9 punktów.

5 Przenalizowano zawartość następujących czasopism: „Bibliotheca Nostra. Śląski Kwartalnik Naukowy” (9 pkt.), „Polish Libraries” (9 pkt.), „Przegląd Biblioteczny” (9 pkt.), „Biblioteka” (8 pkt.), „Praktyka i Teoria Informacji Naukowej i Technicznej” (8 pkt.), „Zagadnienia Informacji Naukowej” (8 pkt.), „Annales Universitatis Paedagogicae Cracoviensis. Studia ad Bibliothecarum Scientiam Pertinentia” (7 pkt.), „Bibliotekarz Podlaski. Ogólnopolskie Naukowe Pismo Bibliotekoznawcze i Bibliologiczne” (7 pkt.), „Biuletyn Biblioteki Jagiellońskiej” (7 pkt.), „Forum Bibliotek Medycznych” (7 pkt.), „Rocznik Bibliologiczno-Prasoznawczy” (7 pkt.), „Rocznik Biblioteki Narodowej” (7 pkt.), „Roczniki Biblioteczne" (7 pkt.)

${ }^{6}$ Kryterium wyszukiwania były hasła przedmiotowe: "biblioteki dla niepełnosprawnych", „biblioteki dla niewidomych”, „niepełnosprawni - bibliotekarstwo - zawód”, „niepełnosprawni - biblioteki”, „niepełnosprawni - czytelnictwo”, „niepełnosprawni - informacja nauko- 
gdzie po selekcji ${ }^{7}$ zarejestrowano 23 teksty. Następnie eksploracji poddano „Przewodnik Bibliograficzny" za lata 2010-2015, gdzie odnaleziono 3 publikacje ${ }^{8}$. Ostatnim już krokiem w procesie rejestracji polskich publikacji do badań była analiza zawartości 13 polskich czasopism z zakresu bibliotekoznawstwa i informacji naukowej, gdzie zarejestrowano 5 tekstów. Łącznie zarejestrowano 31 publikacji, z których analizie poddano 28, gdyż trzy tytuły powtórzyły się $\mathrm{w}$ dwóch źródłach informacji.

\section{ZAGRANICZNE PIŚMIENNICTWO}

Wyodrębniono 9 zasadniczych nurtów badawczych, a w obrębie niektórych z nich usytuowano bardziej szczegółowe klasy tematyczne (Tab. 1). Wyróżniono też grupę, gdzie znalazły się publikacje podejmujące wybrany aspekt funkcjonowania osób niepełnosprawnych w środowisku bibliotecznym, jednak pojawiający się jednorazowo (np. terminologia, programy kształcenia LIS). Uporządkowanie tematyczne poddanej analizom literatury nie było proste, gdyż eksplorowano piśmiennictwo wąskiej specjalności badawczej bibliologii i informatologii. Po zapoznaniu się z zawartością dokumentów, autorka wydzieliła dwie bardziej ogólne grupy tematyczne (bibliotekarstwo dla niepełnosprawnych, dostęp do informacji), pozostałe zaś uporządkowała (z pewnymi modyfikacjami) wg składowych obsługi bibliotecznej, do których zalicza się: budynek i aranżację wnętrza, zasoby, technologie wspomagające, usługi biblioteczne, bibliotekarzy i użytkowników (Fedorowicz, 2010). Ponieważ analizowane dokumenty niejednokrotnie dotyczyły więcej niż jednej kategorii tematycznej, liczba dokumentów przyporządkowanych określonemu zagadnieniu nie daje 136, a suma procentowa nie stanowi 100.

Najliczniej reprezentowane jest piśmiennictwo, które ujęto w kategorii dostęp do informacji. Silny nurt badań dotyczy tu przede wszystkim dostępności do bibliotecznych serwisów WWW i oferowanych tam zasobów (baz danych, katalogów), co z punktu widzenia usieciowienia środowiska informacyjnego i barier, na jakie napotykają w korzystaniu z jego zasobów osoby niepełnosprawne, jest uzasadnione. Biblioteki oferują współcześnie trzy obszary dostępu do zasobów sieciowych: do Internetu (pojmowanego szeroko), do baz danych i do własnego serwisu internetowego, z których

\footnotetext{
wa”, „niepełnosprawni - wydawnictwa”, „biblioteki dla niepełnosprawnych”, „biblioteki dla niewidomych".

${ }^{7}$ Rejestrowano wyłącznie publikacje naukowe, które wpisywały się w obszar badawczy bibliologii i informatologii.

${ }^{8}$ Kryterium wyszukiwania były hasła przedmiotowe: „bibliotekarstwo dla chorych i niepełnosprawnych", "niepełnosprawni a czytelnictwo - Polska - od 1980 r.”, „,biblioteki dla niewidomych Polska - od 1944 r.”, "biblioteki dla niewidomych - zbiory - Polska”, „niepełnosprawni a internet” „niepełnosprawni a komputery”.
} 
Tabela 1

Nurty badawcze w piśmiennictwie zagranicznym dotyczące funkcjonowania osób niepełnosprawnych $\mathrm{w}$ środowisku bibliotecznym i informacyjnym, wyodrębnione na podstawie analizy publikacji z lat 2010-2015 zarejestrowanych w LISTA. Tabela prezentuje je w kolejności od najliczniejszego do najmniej licznego

\begin{tabular}{|c|c|c|}
\hline $\begin{array}{l}\text { Nurty badawcze z podziałem } \\
\text { na klasy tematyczne }\end{array}$ & $\begin{array}{l}\text { Liczba } \\
\text { publikacji }\end{array}$ & $\begin{array}{l}\text { Procentowy udział } \\
\text { w grupie publikacji } \\
\text { zakwalifikowanych } \\
\text { do analizy }\end{array}$ \\
\hline $\begin{array}{l}\text { Dostęp do informacji: } \\
\text { - dostępność serwisów WWW bibliotek i zasobów } \\
\text { jakie udostępniają } \\
\text { - formaty dokumentów (analogowe i cyfrowe) } \\
\text { - biblioteki cyfrowe dla niepełnosprawnych } \\
\text { - dostęp do informacji (ogólnie) }\end{array}$ & $\begin{array}{r}49 \\
24 \\
19 \\
4 \\
2\end{array}$ & $\begin{array}{r}36,02 \\
17,64 \\
13,97 \\
2,94 \\
1,47\end{array}$ \\
\hline $\begin{array}{l}\text { Usługi biblioteczne } \\
\text { - usługi biblioteczne } \\
\text { - historia usług bibliotecznych dla niepełno- } \\
\text { sprawnych }\end{array}$ & $\begin{array}{r}30 \\
27 \\
3\end{array}$ & $\begin{array}{r}22,05 \\
19,85 \\
2,2\end{array}$ \\
\hline $\begin{array}{l}\text { Dostępność bibliotek: } \\
\text { - dostępność usług bibliotecznych } \\
\text { - dostęp architektoniczny, wyposażenie, aranża- } \\
\text { cja wnętrza } \\
\text { - elementy dostępności bibliotek }\end{array}$ & $\begin{array}{r}23 \\
13 \\
6 \\
4\end{array}$ & $\begin{array}{r}16,91 \\
9,55 \\
4,41 \\
2,94\end{array}$ \\
\hline $\begin{array}{l}\text { Użytkownicy } \\
\text { - potrzeby informacyjne, zachowania informacyj- } \\
\text { ne, wykorzystanie informacji, satysfakcja z usług } \\
\text { - bariery w dostępie do bibliotek i informacji } \\
\text { - czytelnictwo }\end{array}$ & $\begin{array}{l}23 \\
12 \\
7 \\
4\end{array}$ & $\begin{array}{r}16,91 \\
8,82 \\
5,14 \\
2,94 \\
\end{array}$ \\
\hline Technologie wspomagające & 12 & 8,82 \\
\hline $\begin{array}{l}\text { Bibliotekarstwo dla niepełnosprawnych: } \\
\text { - działalność bibliotek na rzecz środowiska osób } \\
\text { niepełnosprawnych } \\
\text { - organizacja bibliotekarstwa dla niepełno- } \\
\text { sprawnych } \\
\text { - rola bibliotek we wspieraniu osób niepełno- } \\
\text { sprawnych }\end{array}$ & $\begin{array}{l}9 \\
6 \\
2 \\
1\end{array}$ & $\begin{array}{l}6,61 \\
4,41 \\
1,47 \\
0,73\end{array}$ \\
\hline Projekty & 9 & 6,61 \\
\hline Bibliotekarze & 5 & 3,67 \\
\hline Kwestie prawne & 5 & 3,67 \\
\hline Różne & 4 & 2,94 \\
\hline
\end{tabular}

Źródło: Oprac. własne. 
wszystkie powinny być dostępne dla osób z niepełnosprawnością (Vandenbark, 2010, p. 26). Analizowane teksty najczęściej są rezultatem testowania konkretnych serwisów bibliotecznych i prezentowane są w kontekście obowiązujących standardów dostępności ${ }^{9}$. Inna, węższa klasa tematyczna poświęcona jest zasobom zarówno w postaci analogowej, jak i cyfrowej, adresowanym do osób z niepełnosprawnością dostępowi do nich oraz możliwościom wykorzystania. Kilka publikacji poświęconych jest bibliotekom cyfrowym, zaprojektowanym z myślą o potrzebach użytkowników z niepełnosprawnościa głównie wzroku, którzy korzystają z technologii wspomagających, np. w postaci czytników ekranu, monitorów brajlowskich czy czytników książek cyfrowych.

Istotnym elementem biblioteki są usługi biblioteczno-informacyjne, które również powinny być tak zaprojektowane, by mogły z nich korzystać osoby z niepełnosprawnością. Temu segmentowi działalności bibliotecznej badacze również poświęcają swoją uwagę, prezentując nowe rozwiązania w tym zakresie, dobre praktyki w bibliotekach oraz ofertę dla określonej grupy niepełnosprawnych odbiorców.

Kategorią tematyczną, ściśle związaną z poprzednią, jest aspekt funkcjonowania bibliotek, niezwykle istotny - jeśli nie podstawowy z punktu widzenia osób z niepełnosprawnościa, a mianowicie dostępność tych instytucji. Znalazły się tutaj publikacje poświęcone kryteriom dostępności bibliotek dla osób z niepełnosprawnością. Ponadto analizy będące wynikiem badań prowadzonych w bibliotekach różnych typów, a dotyczących udogodnień architektonicznych, aranżacji wnętrza i wyposażenia, jakim dysponują. Ostatnia już klasa tematyczna opisuje wyniki eksploracji realizowanych w różnych bibliotekach, a dotyczących dostępności usług bibliotecznych.

Zainteresowanie badaczy skupia się także na centralnym niejako punkcie analizowanego obszaru, jakim jest użytkownik z niepełnosprawnością. Badania w tym segmencie koncentrują się na barierach, na jakie napotykają oni w korzystaniu z biblioteki i informacji, potrzebach informacyjnych i zachowaniach informacyjnych osób niepełnosprawnych, ich satysfakcji z usług bibliotecznych, a także czytelnictwie.

Ważnym współcześnie aspektem funkcjonowania osób z niepełnosprawnością w środowisku informacyjnym jest korzystanie z technologii wspomagających (ang. assistive technologies), które umożliwiają osobom

\footnotetext{
9 Standardy i specyfikacje techniczne dotyczące projektowania stron zostały opracowane przez World Wide Web Consortium (W3C) w ramach powstałej w 1996 r. grupy roboczej do spraw dostępności Web Accessibility Initiative (WAI). W 1999 r. WAI opracowało Web Content Accessibility Guidelines (WCAG), który jest wykazem kryteriów wykonania dostępnych stron WWW. Najnowsza wersja WCAG 2.0 została rekomendowana przez W3C w 2008 r. Zob. Web Content Accessibility Guidelines (WCAG) 2.0, [online] [dostęp: 23.08.2016]. Dostępny w WWW: http://www.w3.org/TR/WCAG20/. Polskie autoryzowane tłumaczenie zob. Wytyczne dla dostępności treści stron internetowych 2.0 [online] [dostęp: 23.08.2016]. Dostępny w WWW: http://fdc.org.pl/wcag2/.
} 
niepełnosprawnym całkowicie lub częściowo samodzielny dostęp do informacji. Są one prezentowane w tekstach w kontekście dostępu do informacji, ale także wiedzy i potrzeb użytkowników bibliotek w tym zakresie i niezbędnego wyposażenia bibliotek.

Najbardziej ogólną kategorią tematyczną, co nie znaczy, że najbardziej liczna, było bibliotekarstwo dla niepełnosprawnych. Tutaj znalazły się teksty poświęcone organizacji bibliotekarstwa dla osób z niepełnosprawnością wzroku w poszczególnych krajach oraz działalności poszczególnych bibliotek i organizacji bibliotekarskich na rzecz osób niepełnosprawnych.

W piśmiennictwie zagranicznym omawiane są także projekty realizowane głównie przez biblioteki, których celem jest podniesienie dostępności tych instytucji dla osób niepełnosprawnych, wprowadzenie nowych kategorii usług, włączenie społeczne niepełnosprawnych, czy podniesienie ich kompetencji informacyjnych.

Zdecydowanie mniej uwagi badacze poświęcają bibliotekarzom, których dotyczą badania z zakresu ich umiejętności komunikacyjnych i metod pracy z tytułowymi użytkownikami oraz wiedzy na temat potrzeb osób niepełnosprawnych.

Ostatnia już wyróżniona kategoria tematyczna w zagranicznym piśmiennictwie dotyczy kwestii prawnych, które odnoszą się do prawa autorskiego regulującego kwestie konwertowania standardowych publikacji, ich powielania i udostępniania. $W$ analizowanych publikacjach poruszano też prawne aspekty przeciwdziałania dyskryminacji osób niepełnosprawnych i ich dostępu do informacji.

Najwięcej, bo 76 publikacji dotyczyło ogólnie osób niepełnosprawnych (55,88\%). Jeśli idzie o konkretne typy niepełnosprawności, najwięcej tekstów poświęcono osobom z niepełnosprawnością wzroku (46, co stanowi $33,82 \%)$, następnie osobom ze specyficznymi trudnościami w uczeniu się (ang. specific learning disabilities), do których zalicza się osoby dyslektyczne $(7-5,14 \%)$, osobom $z$ niepełnosprawnością narządu ruchu $(5-3,67 \%)$, osobom z niepełnosprawnością intelektualną $(3-2,2 \%)$, osobom $\mathrm{z}$ autyzmem $(2-1,47 \%)$ i zaledwie jeden tekst osobom $z$ niepełnosprawnością słuchu $(0,73 \%)$.

Wyodrębnione kategorie tematyczne w dużym stopniu pokrywają się z tymi, które zaproponowała Heather Hill, analizując zarejestrowane w „Library and Information Science Abstracts" (LISA) anglosaskie piśmiennictwo naukowe z zakresu bibliotekoznawstwa i informacji naukowej, opublikowane w latach 2000-2010, a dotyczące zagadnienia niepełnosprawności i dostępności. Ustaliła ona, że najliczniejszym nurtem badawczym jest problematyka dostępności do zasobów internetowych, baz danych i oprogramowania. W następnej kolejności znalazły się: usługi dla osób niepełnosprawnych, opisy konkretnych programów/projektów (głównie w zakresie organizowania osobom niepełnosprawnym dostępu do informacji i zaso- 
bów), opisy produktów (przede wszystkim technologie wspomagające), zagadnienia prawne (tu m.in. ustawy antydyskryminacyjne), artykuły różne, działalność organizacji (instytucje biblioteczne działające na rzecz osób z niepełnosprawnościami), zasoby, formaty alternatywne, dostępność (architektoniczna, do tekstów) (Hill, 2013, pp. 139-140). Najwięcej publikacji poświęcono ogólnie osobom z niepełnosprawnością, a następnie osobom niewidomym i słabo widzącym. Bardzo rzadko prowadzono badania w odniesieniu do osób ze specyficznymi trudnościami w nauce, a sporadycznie dotyczące osób z niepełnosprawnością ruchu, słuchu i z niepełnosprawnościami sprzężonymi (Hill, 2013, p. 140).

Oprócz - wskazanego wcześniej - podobieństwa w zakresie liczby i kategorii tematycznych zaproponowanych przez Heather Hill i autorkę tekstu, należy podkreślić fakt, że ustalenia dotyczące częstotliwości podejmowania badań w odniesieniu do dwóch pierwszych grup są identyczne. Zatem dwoma obszarami, w obrębie których lokuje się największa liczba prowadzonych badań są: dostęp do informacji oraz usługi biblioteczne. Pomimo tego, że autorka niniejszego artykułu - w przeciwieństwie do Hill - analizowała zagraniczne piśmiennictwo nie ograniczone do anglosaskiego, uprawnione wydaje się stwierdzenie, że dorobek piśmienniczy w zakresie bibliotekoznawstwa i informacji naukowej dotyczący obsługi bibliotecznej osób niepełnosprawnych oraz ich funkcjonowania w środowisku bibliotecznym i informacyjnym $\mathrm{z}$ lat 2010-2015, jest tematycznie w dużej mierze kontynuacją tego z lat 2000-2010.

\section{POLSKIE PIŚMIENNICTWO}

Problematyka poruszana w polskim piśmiennictwie nie jest tak różnorodna, jak w literaturze zagranicznej. Wynika to z mniejszej liczby publikacji zarejestrowanych w latach 2010-2015, co może być efektem ograniczonej rejestracji w „Polskiej Bibliografii Bibliologicznej”. Wprawdzie autorka przeanalizowała także zawartość „Przewodnika Bibliograficznego" i polskich czasopism naukowych z zakresu bibliologii i informatologii za ten sam okres, jednak żadne z tych źródeł nie rejestruje utworów bibliograficznych w postaci publikacji w pracach zbiorowych, a te co roku ukazują się w niemałej liczbie. Jeśliby przyjąć zaproponowany w poprzedniej części podział na kategorie tematyczne, wyglądałby tak, jak obrazuje to tabela 2.

Nurty badawcze w najnowszym piśmiennictwie polskim $\mathrm{z}$ analizowanego zakresu pokrywają się z tymi podejmowanymi w literaturze zagranicznej, lecz kilka obszarów (dostępność bibliotek, projekty, kwestie prawne) nie doczekało się reprezentacji w literaturze lub pojawiło się jednorazowo (bibliotekarze, usługi biblioteczne). Najintensywniej eksplorowanym obszarem jest tutaj także dostęp do informacji, głównie kwestie dostępu do serwisów WWW i zasobów sieciowych, w mniejszym zakresie - włączania cyfrowego. 
Nurty badawcze w piśmiennictwie polskim dotyczące funkcjonowania osób niepełnosprawnych $\mathrm{w}$ środowisku bibliotecznym i informacyjnym, wyodrębnione na podstawie analizy publikacji z lat 2010-2015 zarejestrowanych w „PBB”, „PB" i czasopismach naukowych. Tabela prezentuje je w kolejności od najliczniejszego do najmniej licznego. Nurty badawcze (lit. zagr.)

\begin{tabular}{|l|c|c|}
\hline \multicolumn{1}{|c|}{$\begin{array}{c}\text { Nurty badawcze z podziałem } \\
\text { na klasy tematyczne }\end{array}$} & $\begin{array}{c}\text { Liczba } \\
\text { publikacji }\end{array}$ & $\begin{array}{c}\text { Procentowy udział } \\
\text { w grupie publikacji } \\
\text { zakwalifikowanych } \\
\text { do analizy }\end{array}$ \\
\hline Dostęp do informacji & 11 & 39,28 \\
\hline Technologie wspomagające & 8 & 28,57 \\
\hline Bibliotekarstwo dla niepełnosprawnych & 5 & 17,85 \\
\hline Użytkownicy & 4 & 14,28 \\
\hline Bibliotekarze & 1 & 3,58 \\
\hline Usługi biblioteczne & 1 & 3,58 \\
\hline Dostępność bibliotek & - & - \\
\hline Projekty & - & - \\
\hline Kwestie prawne & - & - \\
\hline Różne & - & - \\
\hline
\end{tabular}

Źródło: Oprac. własne.

Sporym zainteresowaniem badaczy cieszy się kwestia technologii wspomagających, które odgrywają ogromną rolę w dostępie osób z niepełnosprawnością do informacji. Dość duży odsetek publikacji poświęcony jest działalności konkretnych bibliotek na rzecz wspomnianej grupy (kategoria: bibliotekarstwo dla niepełnosprawnych). Z kolei w grupie tematycznej poświęconej użytkownikom, wszystkie zarejestrowane publikacje dotyczyły czytelnictwa. W porównaniu z piśmiennictwem zagranicznym brakuje badań dotyczących potrzeb informacyjnych i satysfakcji z usług biblioteczno-informacyjnych.

Podobnie, jak w przypadku piśmiennictwa zagranicznego, tematyka połowy analizowanych publikacji ogniskuje się wokół całej zbiorowości osób z niepełnosprawnością (14), a w następnej kolejności wokół problematyki osób z niepełnosprawnością wzroku (10) i z niepełnosprawnością słuchu (3). Odnotowano po jednej publikacji odnoszącej się do środowiska osób z niepełnosprawnością intelektualną i głuchoniewidomych.

\section{PODSUMOWANIE}

Autorka zdaje sobie sprawę, że wybrała tylko jeden z wielu sposobów doboru źródeł informacji do analiz (Sosińska-Kalata, 2013, s. 24-25). Uzyskane wyniki można jednak poddać weryfikacji stosując odmienne kry- 
teria doboru zasobów do badań. Należy zaznaczyć, że przeszukiwano źródła informacji, stosując w przeważającej liczbie hasła przedmiotowe, odnoszące się do ogółu osób z niepełnosprawnością. Użycie haseł odnoszących się do konkretnych typów niepełnosprawności mogłoby dać nieco inne wyniki.

Osoby niepełnosprawne, jako użytkownicy bibliotek i informacji, pozostają w obszarze zainteresowań badaczy w dyscyplinie bibliotekoznawstwa i informacji naukowej, czego dowodem jest specjalny numer czasopisma „Library Quaterly"10 z 2015 r., dotyczący wprawdzie szeroko rozumianego zróżnicowania społecznego, gdzie jednak sporo miejsca poświęcono niepełnosprawnym użytkownikom bibliotek. Niewątpliwie najsilniejszy aktualnie nurt badań w bibliotekoznawstwie i informacji naukowej w omawianym zakresie stanowi dostęp do informacji osób z niepełnosprawnością, obejmujący tematykę dostępu do zasobów internetowych, baz danych, bibliotek cyfrowych i w mniejszym stopniu zasobów w postaci analogowej. W dużej mierze jest on konsekwencją rozwoju technologii informacyjno-komunikacyjnych, którego beneficjentami stały się także osoby z niepełnosprawnością. Po wielu latach „reglamentowania” dostępu do informacji, nowe narzędzia technologiczne pozwoliły na samodzielny, bądź bardziej samodzielny niż wcześniej, dostęp do informacji, zwłaszcza w środowisku osób z niepełnosprawnością wzroku. To z kolei uformowało nowe pole badawcze $\mathrm{w}$ bibliologii $\mathrm{i}$ informatologii. $\mathrm{W}$ porównaniu $\mathrm{z}$ wiodącym nurtem badawczym, ciągle mniejszym zainteresowaniem badaczy cieszą się użytkownicy, których potrzebom bibliotecznym i informacyjnym należałoby podporządkować opracowywanie oferty usług. Widoczny jest zwłaszcza brak polskich analiz poświęconych wspomnianym potrzebom, zainteresowaniom informacyjnym czy satysfakcji z usług bibliotecznych. Skutkować to może pewnym dysonansem na linii oferta biblioteki - oczekiwania użytkownika.

Tytułowy obszar badawczy nadal wymaga analiz, których ważnym efektem winno być stworzenie osobom niepełnosprawnym warunków do korzystania $z$ oferowanych usług bibliotek na równych zasadach ze sprawnymi użytkownikami. Omawiana grupa ciągle jednak napotyka bariery, wśród których wymienia się: brak wiedzy bibliotekarzy na temat istniejących standardów obsługi osób z niepełnosprawnością, brak technologii wspomagających w bibliotekach i wiedzy wśród użytkowników na ich temat, niedostępne urządzenia (np. czytniki e-booków), niedostępne strony internetowe, brak dostępu do baz danych, katalogów i zdigitalizowanych zasobów (np. w repozytoriach i bibliotekach cyfrowych) (Booth, 2012, p. 5-6).

${ }^{10}$ Por. Library Quaterly, vol. 85, iss. 2. Special Isuuse: „Diversity and Library Information Science Education". 


\section{BIBLIOGRAFIA:}

Aharony, Noa (2012). Library and Information Science research areas: A content analysis of articles form the top 10 journals 2007-8. Journal of Librarianship and Information Science, vol. 44, iss. 1, pp. 27-35.

Booth, Char. (2012). Why Accessibility? Library Technology Reports, vol. 48, iss. 7, pp. 5-6.

Davies, Eric J. (2007). An overview of international research into the library and information needs of visually impaired people. Library Trends, vol. 55, no. 4, pp. 785-795.

Fedorowicz, Małgorzata (2010). Człowiek niepetnosprawny w bibliotece publicznej. Toruń: Wydaw. Naukowe UMK.

Głowacka, Ewa. (2008). Główne współczesne kierunki badań z zakresu bibliotekoznawstwa. Przeglad Biblioteczny, z. 1, s. 22-27.

Hill, Heather (2013). Disability and accessibility in the library and information science literature: A content analysis. Library and Information Science Research, vol. 35, iss. 2, pp. 137-142.

MNiSW (2015). Część B wykazu czasopism naukowych, załącznik do Komunikatu Ministra Nauki i Szkolnictwa Wyższego z dnia 18 grudnia 2015 r. w sprawie wykazu czasopism naukowych wraz z liczba punktów przyznawanych za publikację w tych czasopismach, [online]. Ministerstwo Nauki i Szkolnictwa Wyższego; [dostęp: 06.07.2016]. Dostępny w WWW: <http:// www.nauka.gov.pl/g2/oryginal/2015_12/57768c2cb322779eb01734014ff4be38.pdf>.

MNiSW (2016). Komunikat Ministra Nauki i Szkolnictwa Wyższego z dnia 1 lipca 2016 r. o sprostowaniu komunikatu w sprawie wykazu czasopism naukowych wraz z liczba punktów przyznawanych za publikacje w tych czasopismach, [online]. Ministerstwo Nauki i Szkolnictwa Wyższego; [dostęp: 06.07.2016]. Dostępny w WWW: <http://www.nauka.gov.pl/g2/ oryginal/2016_07/126cc9965db69987a799154c9ac8a22b.pdf>.

Sosińska-Kalata, Barbara (2013). Obszary badań współczesnej informatologii (nauki o informacji). Zagadnienia Informacji Naukowej, nr 2, s. 9-41.

Szablewski, Maciej (2016). Temat: Polska Bibliografia Bibliologiczna, [online]. Do: Małgorzata Fedorowicz-Kruszewska. 28 czerwca 2016. Korespondencja osobista.

Vandenbark, Todd R. (2010). Tending a Wild Garden: Library Web Design for Persons with Disabilities. Information Technology \& Libraries, vol. 29, iss. 1, pp. 23-29.

Artykut w wersji poprawionej wptynąt do Redakcji 4 marca 2017 r. 
MAŁGORZATA FEDOROWICZ-KRUSZEWSKA

Institute of Information and Book Studies

Nicolaus Copernicus University in Torun

e-mail: fema@umk.pl

\section{THE DISABLED IN LIBRARIES - RESEARCH TRENDS IN FOREIGN AND POLISH LITERATURE IN THE FIELD OF LIBRARY AND INFORMATION SCIENCE}

KEYWORDS: The disabled. Disabilities. Library services. Library information services.

ABSTRACT: Thesis/Objective - The author intends to present current research trends in the library and information science (LIS) literature focused on the library and information services for the disabled and compare research topics covered by foreign and Polish literature in this field. Research methods - The critical literature review was used to analyze the content of foreign and Polish LIS literature published in the years 2010-2015. The literature was found via „Library, Information Science \& Technology Abstracts” (LISTA), „Polska Bibliografia Bibliologiczna (Polish Book Studies Bibliography)”, „Przewodnik Bibliograficzny (Polish National Bibliography)", and Polish LIS journals. Results and conclusions - The author identifies 9 main themes in foreign LIS literature referring to the library and information services for the disabled, whereas only 6 such themes appear in Polish LIS literature. The strongest theme in LIS literature covers issues of accessing information by the disabled, including such subcategories as: access to Internet resources, databases and digital libraries and, to a lesser extent, to the resources on non-digital carriers. 